\title{
Propuesta de índices texturales para la cuantificación de la distribución de las fases en el clínker de cemento portland
}

\author{
Proposed textural indexes to quantify \\ the distribution of the portland \\ cement clinker phases
}

\author{
ANGEL RODRIGUEZ REY, MODESTO MONTOTO, LOPE CALLEJA Y VICENTE G. RUIZ DE ARGANDOÑA \\ Departamento de Geología. Area de Petrologia. Universidad de Oviedo. 33080-OVIEDO. ESPAÑA \\ Fecha de recepción: 11 mayo 1988
}

\section{$\cdot R E S U M E N$}

Se proponen unos parámetros texturales para la cuantificación de la distribución de las fases en el clínker de cemento Portland. Estos parámetros, que se determinan mediante microscopia óptica por luz reflejada, permiten la caracterización de la homogeneidad del clínker. Se presenta un ejemplo de su aplicación a un clínker industrial de cemento Portland.

\section{SUMMARY}

Some textural parameters to quantify the distribution of the Portland cement clinker phases are proposed. These parameters are evaluated under reflected-light microscopy and allow the characterization of clinker homogeneity. Their application to an industrial cement clinker is presented.

\section{INTRODUCCION}

Los clínkeres industriales presentan cantidades más o menos importantes de concentraciones o nidos de algunas fases, como resultado de irregularidades durante ciertas etapas de su fabricación (molienda, homogeneización, etc), o debido a fenómenos de segregación.

Por lo tanto, la distribución de las fases es una característica textural importante que debe ser estudiada y cuantificada ya que suministra información muy valiosa que puede ser utilizada para el control de producción.

Algunos autores han propuesto clasificaciones texturales del clínker de cemento Portland que incluyen estimaciones cualitativas de la mencionada distribución de fases (1), (2). Sin embargo, algunas veces es muy dificil la clasificación de los clínkeres industriales según estos métodos.

Así pues, y como solución alternativa, se presentan unos nuevos parámetros texturales para cuantificar la homogeneidad del clínker.

\section{INTRODUCTION}

Industrial clinkers present a more or less important amount of concentrations or nests of some phases as a result of irregularities during certain steps in production (grinding, mixing, etc) or due to seggregation phenomena.

So, phase distribution is an important textural characteristic to be studied and quantified as it provides very valuable information which can be used for controlling the industrial clinker production.

Some authors have proposed textural classifications of the Portland cement clinker which include qualitative estimations of the mentioned phase distribution (1), (2). However, it is sometimes very difficult to classify industrial clinkers acconding to these methods.

Therefore, as an alternative solution, new textural parameters to quantify the clinker homogeneity are presented. 


\section{INDICE DE HOMOGENEIDAD}

Para caracterizar la distribución de cada una de las fases del clínker se propone un índice de homogeneidad, $\mathrm{HI}$ (fase $P$ ); se define como la relación entre el volumen ocupado por todos los nidos de la fase, $V n(P)$, y el volumen total ocupado por dicha fase, $V(P)$.

\section{HOMOGENEITY INDEX}

To characterize the distribution of each of the phases an homogeneity index is proposed, $\mathrm{HI}$ (phase P); it is defined as the relation between the volume occupied by all the nests of the phase, $\mathrm{Vn}(\mathrm{P})$, and the total volume occupied by that phase, $V(P)$.

$$
H I(P)=\frac{V n(P)}{V(P)} \cdot 100
$$

HI puede variar entre 0 (caso de una distribución homogénea) y 100 (cuando toda la fase $P$ aparece como nidos).

Para determinar $V n(P)$ pueden utilizarse tres procedimientos clásicos de medida: contaje de puntos, de lineas y de áreas, cuyas ventajas e inconvenientes son bien conocidos en estereología (3).

En este caso resulta muy apropiado el análisis lineal ya que no es tan laborioso como el análisis de áreas y suministra más información sobre otras características de la distribución de las fases que el contaje de puntos.

En el procedimiento operatorio se mide un número apropiado de gránulos de clínker, en función de su granulometría.

La medida se hace sobre secciones pulidas convenientemente atacadas, mediante microscopía óptica por luz reflejada. Se selecciona aleatoriamente un diámetro en cada gránulo, determinándose entonces los siguientes parámetros:

$n$ : número de nidos intersectados por el diámetro seleccionado.

li: longitud intersectada de cada nido.

Id: longitud del diámetro seleccionado.

El procedimiento se repite en todos los gránulos que se van a medir. Si se han estudiado " $m$ " gránulos, al final se obtienen los siguientes parámetros:
$\mathrm{HI}$ can range from 0 (perfect distribution) to 100 (all the phase P appears as nests).

To determine $\mathrm{Vn}(\mathrm{P})$ there classic counting procedures can be used: poind, linear and areal, whose advantages and disadvantages are well known in Stereology (3).

In this case, the linear counting procedure has been found very convenient, since it is not as laborious as area counting and it provides more information about other characteristics of phase distribution than point counting can do.

In the measurement procedure a proper number of granules, depending on the clinker granulometric distribution are used.

The evaluation is carried out on suitably etched polished sections, under reflected-light microscopy. An aleatory diameter in each granule is selected and the following parameters are determined:

$\mathrm{n}$ : number of nests intersected by the chosen diameter.

li: intersected lenght of each nest.

Id: lenght of chosen diameter.

The procedure is repeated on all the chose granules. If " $\mathrm{m}$ " granules are measured, the final parameters are:

$$
N=\sum_{1}^{m} n, \quad L i=\sum_{1}^{m} l i, \quad L=\sum_{1}^{m} l d,
$$

donde $N$ es el número total de nidos encontrados en todos los gránulos observados; $L i$ es la suma de todas las intersecciones medidas, y $L$ es la suma de todos los diámetros de referencia. where $\mathrm{N}$ is the total number of nests found in the observed granules; $\mathrm{Li}$ is the sum of all the intersections measured, and $\mathrm{L}$ is the sum of all the diameters of reference. 
A partir de estos datos puede obtenerse el porcentaje de nidos:
From these data the volumetric percentage of nests can be obtained:

$$
V n(P)=\frac{L i}{L} \cdot 100
$$

así como su coeficiente de variación (3).

La composición mineralógica del clínker, o al menos el porcentaje volumétrico de la fase en estudio, $V(P)$, puede obtenerse

simultáneamente, aunque puede determinarse en otra etapa mediante contaje de puntos, por ejemplo.

Los valores de $\mathrm{HI}$ pueden estar afectados por un error despreciable puesto que los nidos no son absolutamente compactos $y$, como resultado, el volumen real de los nidos de la fase $P$ es más pequeño que el medido.

En caso de nidos de forma muy irregular, que son intersectados más de una vez por el diámetro de referencia, "li" será la suma de todas las intersecciones; para el cómputo de " $n$ " se tendrá en cuenta que todas ellas pertenecen al mismo nido.

De forma complementaria, y a partir de los mismos datos, pueden definirse otros parámetros relativos a la distribución de fases:

- Densidad lineal de nidos $(D)$, definida como el número de nidos por unidad de longitud: as well as its coefficient of variation (3).

The mineralogic composition of clinker, or ar least the volumetric percentage of the phase under study, can be simultaneously obtained although it can be separately evaluated by point counting, for example.

Values of $\mathrm{HI}$ can be affected by a negligible error since nests do not use to be compact and, as a result, the real volume of the nests of $\mathrm{P}$ is smaller than the measured one.

In case of very irregular shaped nests which are intersected more than one time by the diameter of reference, "li" will be the sum of all the intersections; for the computing of " $\mathrm{n}$ ", it must be considered that all of them belong to the same nest.

In a complemetary way, and from the same data, other parameters of the phase distribution can be defined:

- Linear density of nests, D, defined as the number of nests per lenght unit.

$$
D=\frac{N}{L}
$$

- Cuerda media de los nidos, $(C)$, que es la media de todas las intersecciones y que suministra una estimación del tamaño medio de los nidos en un clínker:
- Mean chord length, C, which is the mean of all the intersections, and provides an estimation of the mean size of the nests in a clinker.

$$
C=\frac{L i}{N}
$$

La distribución de longitudes de "li" suministra información más específica sobre la inhomogeneidad del clínker, puesto que las intersecciones pueden ser usadas como estimación insesgada del volumen de los nidos, (4).
The length distribution of "li" provides more specific information about the inhomogeneity of the clinker, since the intersections can be used for unbiased estimations of the volume of the nests (4). 


\section{EJEMPLO DE UTILIZACION}

Los parámetros propuestos han sido utilizados con éxito por los autores (5). A continuación se presenta, como ejemplo de su aplicación, la cuantificación de la heterogeneidad de la distribución de la belita de un clínker industrial. El clínker seleccionado presenta una distribución muy irregular de sus fases, especialmente la de la belita que aparece en grandes nidos de contornos muy irregulares (fig. 1).

Los parámetros determinados se presentan en la Tabla I. El porcentaje volumétrico de la belita se midió mediante contaje de puntos en secciones pulidas atacadas. La distribución de la longitud de las cuerdas aparece en la figura 2.

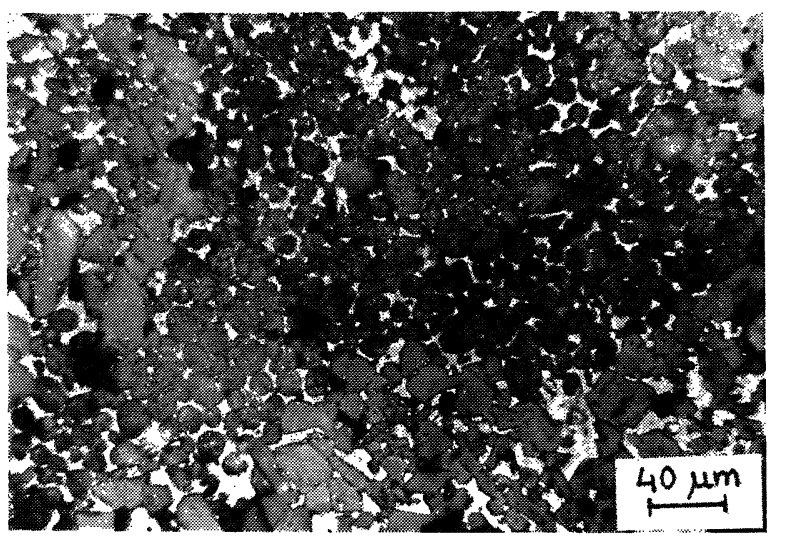

Fig. 1.-Grandes nidos de forma irregular de belita en el clínker estudiado como ejemplo. Microscopía óptica de reflexión.

Fig. 1.-Large and irregularly shaped nests of beiite in the clinker of the example (Reflected light microscopy).

\section{EXAMPLE OF USE}

The proposed parameters have been successfully used by the authors (5). The quantified heterogeneity of the distribution of belite in an industrial clinker, as an example of application, follows here. This selected clinker shows a very irregular distribution of its phases, especially belite which appears in large, irregularly contourned nests (Fig. 1).

The parameters obtained are listed in Table 1. The volume of belite was determined with a point counter using etched polished sections. The distributions of chords length is presented in fig. 2.

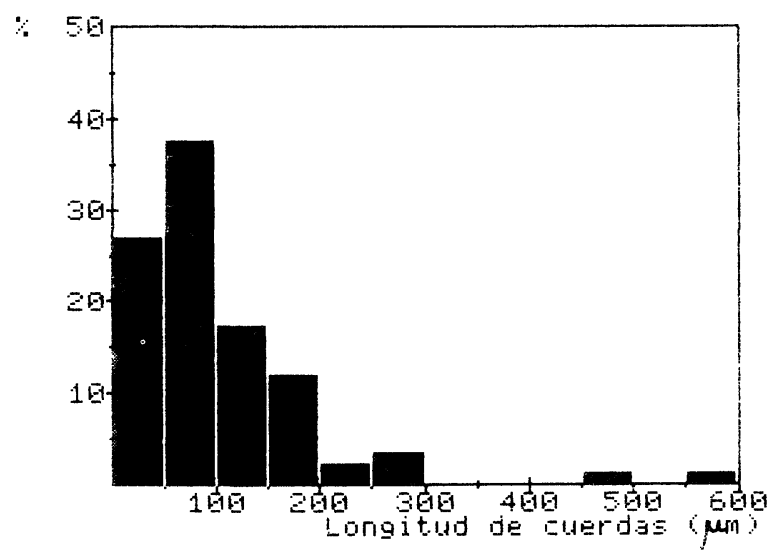

Fig. 2.-Distribución de las longitudes de las cuerdas (en $\mu \mathrm{m})$ de los nidos medidos en el clínker del ejemplo.

Fig. 2.-Distribution of chords length $(\mu \mathrm{m})$ of the measured nests.

TABLA I (TABLE I)

Parámetros de homogeneidad de la belita del clínker del ejemplo (Homogeneity parameters of the belite)

\begin{tabular}{|c|c|c|}
\hline Parámetro (Parameter) & Símbolo (Symbol) & Valor (Valye) \\
\hline Número de nidos medidos (Number of measured nests) & $N$ & 94 \\
\hline Longitud total de nidos medidos (Total length of measured nests) & $\mathrm{Li}$ & $9,720 \mathrm{~mm}$ \\
\hline Longitud total de diámetros medidos (Total length of diameters) & $L$ & $109,9 \mathrm{~mm}$ \\
\hline Volumen de belita (Volume of belite) & $V\left(C_{2} S\right)$ & $15,91 \%$ \\
\hline Volumen de nidos de belita (Volume of belite nests) & $\mathrm{Vn}\left(\mathrm{C}_{2} \mathrm{~S}\right)$ & $8,84 \%$ \\
\hline Indice de homogeneidad de la belita (Homogeneity index of belite) & $\mathrm{HI}\left(\mathrm{C}_{2} \mathrm{~S}\right)$ & 56 \\
\hline Densidad lineal de nidos (Linear density of nests) & $\mathrm{D}$ & $\begin{array}{r}0,86 \text { nidos } / \mathrm{mm} \\
\text { (nests } / \mathrm{mm} \text { ) }\end{array}$ \\
\hline Cuerda media de los nidos (Mean chord length) & 0 & $103,4 \mu \mathrm{m}$ \\
\hline
\end{tabular}




\section{CONCLUSIONES}

Los parámetros texturales propuestos (índice de heterogeneidad, densidad lineal de nidos y longitud media de las cuerdas) pueden ser útiles para caracterizar cuantitativamente la distribución de las fases del clínker y su homogeneidad textural. En consecuencia, las variaciones a lo largo del tiempo de estos parámetros podrían utilizarse como criterio para detectar irregularidades durante el proceso industrial de fabricación del clínker.

\section{CONCLUSIONS}

The proposed textural parameters (homogeneity index, linear density of nests and mean chord length) can be useful to characterize quantitatively, the distribution of clinker phases and its textural homogeneity. Consequently, the variations with time in those parameters could be considered as a suitable criteria to detect irregularities during industrial clinker production.

\section{BIBLIOGRAFIA}

(1) SUDAKAS, L. G.; KAPLYA, A. F.; FEDIK, A. A. \& SHEIKO, A. N.: "Dependence of cement quality on clinker textural properties". Tsement, No. 2, (1975), pp. 19-20.

(2) OKOROKOV, S. D.; VOLKONSKII, B. V.; LEVINA, E. A. \& TSEITLIN, Y. M.: "Correlation between clinker composition, structure and properties". Tsement, No. 6, (1975), pp. 8-18.

(3) UNDERWOOD, E. E.: Quantitative stereology. Addison-Wesley Publ. Co. Reading, Massachussets, 1970.

(4) CRUZ-ORIVE, L. M.: Particle number can be estimated using a disector of unknown thickness: the selector. Journal of Microscopy, Vol. 145, Part. 2, 1987, pp. 121-142.

(5) RODRIGUEZ REY, A.: Aplicación de la microscopia óptica y electrónica al estudio mineralógico y textural del clínker de cemento Portland. Tesis Doctoral. Universidad de Oviedo, 1986.

\section{publicación del IETcc/CSIC}

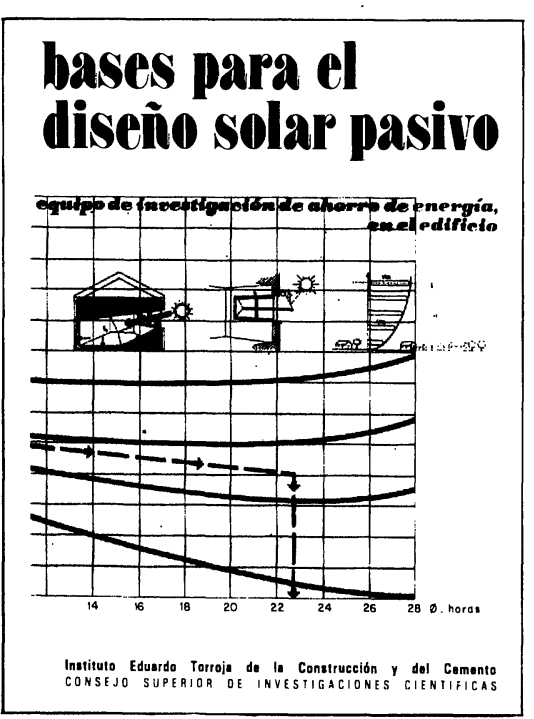

Equipo de Ahorro de Energía en el edificio

Dirección y coordinación: Arturo Garcia Arroyo

M. a José Escorihuela José Luis Esteban

José Miguel Frutos

Manuel Olaya

Bernardo Torroja selectividad en la aplicación de los sistemas y procedimientos pasivos dando origen a un ecumenismo arquitectónico solar, al margen de las condiciones climáticas y funcionales especificas de cada caso y lugar

En este libro, utilizando criterios y metodologia pedagógicos, se dan los fundamentos e instru mentos teórico-prácticos necesarios para el planteamiento de todo proyecto arquitectónico solar pasivo, de acuerdo con los principios éticos y económicos de conservación y ahorro de energia. Es decir: respeto de los presupuestos bioclimáticos, búsqueda de la máxima captación y acumulación de la radiación solar, y esmero en el aislamiento térmico de los cerramientos.

Un volumen encuadernado en cartulina ibiza plastificada, a cinco colores, de $16 \times 23 \mathrm{~cm}$, compuesto de 216 páginas, 217 figuras, 87 gráficos, 19 tablas y 10 cuadros. 